\title{
Processing potential of jellies from subtropical loquat cultivars
}

\author{
Paula Nogueira CURI ${ }^{1}$, Paulyene Vieira NOGUEIRA ${ }^{1}$, Aline Botelho de ALMEIDA², \\ Cynara dos Santos CARVALHO ${ }^{2}$, Rafael PIO ${ }^{1}$, Moacir PASQUAL ${ }^{1}$, Vanessa Rios de SOUZA ${ }^{2 *}$
}

\begin{abstract}
To increase the availability to consumers and add more value to loquat (Eriobotrya japonica Lindl.), which is a very perishable and seasonal fruit, and in order to identify which cultivars grown in subtropical regions are more suitable for jelly processing, the objective of this study was to evaluate the influence of different loquat cultivars (Fukuhara, Kurisaki, Mizumo, Mizuho and Mizauto) grown in subtropical regions of Brazil on the physicochemical characteristics, rheological properties and sensory acceptance of the resulting jelly. Based on sensory acceptance the most suitable loquat cultivars for jelly processing are Kurisaki and Mizuho. In this study it was found that the consumer prefers a more acidic, less sweet, less firm or softer loquat jelly, clearer with a more intense red color.
\end{abstract}

Keywords: Eriobotrya japonica; jelly; sensory quality; consumer profile.

Practical Aplications: It was possible to verify which loquat cultivars are more suitable for processing to jelly.

\section{Introdution}

The loquat (Eriobotrya japonica Lindl.) originates from Asia (Japan, China and India), where it is intensively cultivated. Although it is a typically subtropical fruit, it fits well in temperate and tropical regions (Morton, 1987; Gong et al., 2015). The loquat has been cultivated for over 2000 years and the cultivated area has tremendously increased in recent decades (Lin, 2007). In Brazil, the loquat is an excellent alternative crop for diversification of rural properties, especially at its fruit ripening time, which is concentrated between July and September, when there is lack of other fruits on the market. The main cultivars explored in tropical regions in South America are Fukuhara, Mizumo, Kurisaki, Mizuho and Mizauto (Nogueira et al., 2015), because of the quality of their fruit, chemical composition and yield performance (Hasegawa et al. 2010). The Mizauto cultivar is endowed with good agronomic characteristics and features high productivity and good fruit quality, the Mizuho is characterized by presenting large fruit, juicy pulp, moderately acidic sweet flavor and is widely accepted for consumption (Ojima et al., 1999). The fruits of Mizumo cultivars are large and acidic (Pio et al., 2007). The loquat Fukuhara, its fruits are large, with firm and fleshy pulp and strongly sweet-acidic flavor (Sanches et al., 2011).

The increase in loquat consumption is related mainly to the attractive and distinctive flavor of the fruit and their nutritional and functional characteristics. The loquats are rich in galacturonic and malic acid, flavonoids, carotenoids and other antioxidants, located in the skin and pulp of the fruit (Ferreres et al., 2009). It also has a high pectin concentration, which favors the industrial processing in the manufacture of jellies, an activity not yet commercially exploited (Hasegawa et al., 2010).
The consumption of loquats in fresh form is limited due to limited post-harvest life (Cai et al., 2006). This fruit has a high polyphenol oxidase enzyme activity, which promotes its rapid darkening, especially after mechanical damage during transport and storage (Zhang \& Shao, 2015). Combined with seasonality and the limitation of production areas, one way to increase availability to the consumer and even more value to the end product is processing or industrialization, through the preparation of juices, jams and jellies (Hasegawa et al., 2010). According to Zhang et al. (2015) loquat processing has rarely been investigated. Various studies have demonstrated that the fruit cultivar has an influence on its composition, suggesting that the cultivar can influence on the physicochemical, rheological and sensory characteristics of the products obtained after processing (Maro et al., 2013; Souza et al., 2014; Curi et al., 2015) as well as on the antioxidant activity and bioactive compounds (Souza et al., 2015).

In this context, the objective of this study was to evaluate the influence of different loquat cultivars (Fukuhara, Kurisaki, Mizumo, Mizuho and Mizauto) grown in subtropical regions of Brazil on the physicochemical characteristics, rheological properties and sensory acceptance of the resulting jelly in order to identify cultivars with the greatest potential for industrial use.

\section{Materials and methods}

\subsection{Ingredients}

The jellies were prepared from five loquat cultivars; Fukuhara, Kurisaki, Mizumo, Mizuho, Mizauto. These cultivars were harvested in the morning in São Bento do Sapucaí, São Paulo 
- Brazil, at their physiological maturity, determined by color and fruit size, and were immediately transported to the Post Harvest Laboratory and cold-stored at $4{ }^{\circ} \mathrm{C}$ until processing time. In addition to the fruit, sucrose and high-methoxyl pectin (Danisco, SP, Brazil) were used for the preparation of the jellies.

\subsection{Jelly processing}

Five loquat jellies were prepared and the variation between the formulations was only the loquat cultivar. The preparation of the jelly was conducted in the Plant Product Processing Laboratory.

To obtain the pulp the fruits were cut into four parts and had the seeds removed, they were then mixed with water at a 1:4 proportions and heated for 30 minutes. The paste obtained was then finely sieved in order to obtain the clarified juice. The percentages of ingredients used for preparation of the jellies were $50 \%$ fruit pulp, $50 \%$ sugar and $1.5 \%$ high methoxyl pectin. For the preparation of jellies, sugar was added in the fruit pulp and then the processing was carried out in an open pan heated by a gas flame (Macanuda, SC, Brazil). After boiling, pectin was added. At the end of the process, when the soluble solids reached $65^{\circ}$ Brix, heating was stopped. The total soluble solids were determined using an RT-82 portable refractometer.

\subsection{Physicochemical analysis}

To characterize the different loquat cultivars, the analysis of length, diameter, mass, total soluble solids, total acidity, SS / total acidity (ratio), $\mathrm{pH}$, texture and color $\left(\mathrm{L}^{*}, \mathrm{a}^{\star}\right.$ and $\mathrm{b}^{*}$ ) was made in the fresh fruits. In the jellies, soluble solids, $\mathrm{pH}$, total acidity, color $\left(\mathrm{L}^{*}, \mathrm{a}^{*}\right.$ and $\left.\mathrm{b}^{*}\right)$ and texture profile analyses (TPA) were conducted. The analyses were performed in the Post Harvest Laboratory in three repetitions.

The total acidity, soluble solids and $\mathrm{pH}$ values were determined according to the Instituto Adolfo Lutz (2005). The color was determined according to the method described by Gennadios et al. (1996). The $L^{*}, a^{*}$ and $b^{*}$ values were determined using a Minolta CR 400 colorimeter (Konica Minolta Sensing Americas, Inc., New Jersey, USA) with standards and D65 CIELab.

For conducting fruit firmness, we measured the force required for a $3 \mathrm{~mm}$ probe coupled to a digital penetrometer, Instrutherm PTR-300 (Instrutherm, São Paulo, Brazil). The determinations were performed at two separate points on the fruit and the results expressed in Newtons $(\mathrm{N})$.

The length and diameter of fruit were measured with the aid of a digital caliper $150 \mathrm{~mm}$ (Kingtools, São Paulo, Brazil), and average fruit weight was determined by individual weighing of each fruit with the aid of a semi - analytical scale Shimadzu AUX220, (Shimadzu of Brazil, São Paulo, Brazil).

\subsection{Texture profile analysis}

The texture profile analyses (TPA) of the jellies using a Stable Micro Systems TA-XT2i texturometer (Stable Micro Systems, Goldaming, England) were performed in penetration mode under the following conditions: a pre-test speed of $1.0 \mathrm{~mm} / \mathrm{s}$, a test speed of $1.0 \mathrm{~mm} / \mathrm{s}$, a post-test speed of $1.0 \mathrm{~mm} / \mathrm{s}$, a time interval between penetration cycles of $10 \mathrm{~s}$, a distance of $40.0 \mathrm{~mm}$ and a compression with a $6.0 \mathrm{~mm}$ diameter cylindrical aluminum probe. The jelly samples were compressed by approximately $30 \%$. The parameters analyzed were hardness, adhesiveness, springiness, cohesiveness, gumminess and chewiness (Friedman et al., 1963; Bourne, 1968; Van Vliet, 1991).

\subsection{Sensory analysis}

Sensory analysis was performed in the Sensory Analysis Laboratory. An acceptance test was conducted with 80 consumers ( 50 females and 30 males) aged between 18 and 50 years, where the evaluated attributes were color, taste, consistency and overall liking, through a 9-point hedonic scale ( $1=$ extremely dislike, 9 = extremely like) (Stone \& Sidel, 1993). Each taster assessed, on average, 5 grams of each loquat jelly formulation, which were served in $50 \mathrm{~mL}$ plastic cups coded with 3 digits in a monadic manner and in a balanced order (Wakeling \& MacFie, 1995). The tasters were instructed in the use of the hedonic scale and to drink water between samples. The sensory analyses were performed according to the Ethics Committee of the Federal University of Lavras, approval number 893.639. The participants were informed about the sensory tests and provided written consent.

\subsection{Statistical analysis}

To compare the loquat cultivars regarding the physicochemical characteristics and to compare the loquat jellies regarding the physicochemical, rheological and sensory characteristics, initially a univariate statistical analysis (ANOVA) and Tukey mean test were used to verify if there was a difference between samples at a significance level of $5 \%(\mathrm{p} \leq 0.05)$.

To correlate the physicochemical and textural characteristics with different jelly formulations, the physicochemical and texture data were analyzed by principal component analysis (PCA). For easy viewing of the jelly formulation sensory acceptance and to correlated with the physicochemical and rheological parameters, a 3-way external preference map obtained by PARAFAC (Nunes et al., 2011) was elaborated.

Data analysis was performed with SensoMaker software version 1.6 (Pinheiro et al., 2013).

\section{Results and discussion}

\subsection{Physical and physicochemical analysis of loquat cultivars}

The average values and the average test of the physical and physicochemical properties evaluated for the different cultivars are shown in Table 1.

The loquat cultivars showed significant differences $(\mathrm{p} \leq 0.05)$ for average length, and diameter, unit weight, soluble solids, total acidity, ratio, $\mathrm{pH}$, firmness and color parameter $\mathrm{a}^{\star}$. For the parameters $\mathrm{L}^{*}, \mathrm{~b}^{*}$, Croma and Hue significant differences were not observed.

As for the size and weight parameters of loquats, from Table 1, it can be verified that in the case of the average fruit length the Fukuhara cultivar had the largest dimensions, $47.70 \mathrm{~mm}$ of average 
Table 1. Average length (AL), average diameter (AD), unit weight (UW), total soluble solids (SS), total acidity (TA), solids/acidity ratio (Ratio), firmness (Firm.), $\mathrm{pH}$ and color $\left(\mathrm{L}^{*}, \mathrm{a}^{*}, \mathrm{~b}^{*}\right.$, Croma $\left.\mathrm{e}^{\circ} \mathrm{Hue}\right)$ in loquat cultivars.

\begin{tabular}{cccccccccccccc}
\hline Cultivars & $\begin{array}{c}\text { AL } \\
(\mathbf{m m})\end{array}$ & $\begin{array}{c}\text { AD } \\
(\mathbf{m m})\end{array}$ & $\begin{array}{c}\text { UW } \\
(\mathbf{g})\end{array}$ & $\begin{array}{c}\text { SS } \\
(\mathbf{o} \text { Brix })\end{array}$ & $\begin{array}{c}\text { TA } \\
(\%)\end{array}$ & Ratio & pH & $\begin{array}{c}\text { Firm. } \\
(\mathbf{N})\end{array}$ & $\mathbf{L}^{*}$ & $\mathbf{a}^{*}$ & $\mathbf{b}^{*}$ & Croma $^{\mathrm{H}}$ Hue \\
\hline Fukuhara & $47.70^{\mathrm{a}}$ & $38.11^{\mathrm{a}}$ & $34.23^{\mathrm{a}}$ & $9.87^{\mathrm{b}}$ & $0.42^{\mathrm{c}}$ & $23.79^{\mathrm{b}}$ & $3.56^{\mathrm{a}}$ & $19.48^{\mathrm{c}}$ & $58.21^{\mathrm{a}}$ & $11.53^{\mathrm{a}}$ & $38.84^{\mathrm{a}}$ & $40.53^{\mathrm{a}}$ & $73.47^{\mathrm{a}}$ \\
Mizumo & $40.44^{\mathrm{bc}}$ & $34.91^{\mathrm{a}}$ & $25.40^{\mathrm{c}}$ & $10.23^{\mathrm{b}}$ & $0.75^{\mathrm{b}}$ & $13.70^{\mathrm{c}}$ & $2.87^{\mathrm{c}}$ & $19.27^{\mathrm{c}}$ & $59.45^{\mathrm{a}}$ & $9.68^{\mathrm{ab}}$ & $35.62^{\mathrm{a}}$ & $36.91^{\mathrm{a}}$ & $74.80^{\mathrm{a}}$ \\
Kurisaki & $43.77^{\mathrm{ab}}$ & $36.73^{\mathrm{a}}$ & $27.47^{\mathrm{b}}$ & $8.63^{\mathrm{d}}$ & $1.22^{\mathrm{a}}$ & $7.07^{\mathrm{d}}$ & $2.70^{\mathrm{e}}$ & $39.15^{\mathrm{b}}$ & $61.27^{\mathrm{a}}$ & $6.71^{\mathrm{a}}$ & $36.76^{\mathrm{a}}$ & $37.37^{\mathrm{a}}$ & $79.66^{\mathrm{a}}$ \\
Mizuho & $44.52^{\mathrm{a}}$ & $35.36^{\mathrm{a}}$ & $27.23^{\mathrm{b}}$ & $9.40^{\mathrm{c}}$ & $1.10^{\mathrm{a}}$ & $8.55^{\mathrm{cd}}$ & $2.78^{\mathrm{d}}$ & $56.48^{\mathrm{a}}$ & $57.50^{\mathrm{a}}$ & $9.67^{\mathrm{ab}}$ & $36.39^{\mathrm{a}}$ & $37.65^{\mathrm{a}}$ & $75.12^{\mathrm{a}}$ \\
Mizauto & $37.02^{\mathrm{c}}$ & $31.12^{\mathrm{b}}$ & $19.97^{\mathrm{d}}$ & $15.47^{\mathrm{a}}$ & $0.44^{\mathrm{c}}$ & $35.21^{\mathrm{a}}$ & $3.20^{\mathrm{b}}$ & $14.30^{\mathrm{c}}$ & $52.15^{\mathrm{a}}$ & $9.01^{\mathrm{ab}}$ & $36.27^{\mathrm{a}}$ & $37.37^{\mathrm{a}}$ & $76.05^{\mathrm{a}}$ \\
\hline
\end{tabular}

Mean values with common letters in the same column indicate that there is no significant difference among samples $(\mathrm{p} \leq 0.05)$ from Tukey's mean test. Total acidity: $\mathrm{g}$ citric acid/100 $\mathrm{g}$ f.w.

length and $38.11 \mathrm{~mm}$ of average diameter. The Mizauto cultivar differed from other cultivars showing the smaller dimensions, $37.02 \mathrm{~mm}$ and $31.12 \mathrm{~mm}$ of average length and diameter, respectively. Consequently, the Fukuhara cultivar differed from other cultivars showing the highest unit weight (34.23 g) and Mizauto was the cultivar with lower unit weight (19.97 g). These results are in agreement with Pio et al. (2007) who found that average length and diameter in the range of 30.00 to $40.00 \mathrm{~mm}$ in various loquat cultivars from eastern São Paulo.

The soluble solids content in the loquat cultivars ranged from 8.63 to $15.47^{\circ} \mathrm{Brix}$, the acidity ranged from 0.42 to $1.22 \mathrm{~g}$ citric acid/100 g, a ratio of 7.07 to 35.21 and the $\mathrm{pH}$ ranged from 2.70 to 3.56 . These parameters are extremely important as they indicate the ultimate destination of fruits, consumption in natura or processed form.

The soluble solids content is associated with the amount of sugars and organic acids. Since consumers prefer sweeter fruits, this is an important characteristic of products sold to be eaten fresh (Silva et al., 2002). Thus, the fruits with the highest possibility of acceptance are those that have higher soluble solids levels.

Acidity is one of the factors that compromise the classification of fruit based on flavor. Fruit with acidity levels ranging from 0.08 to $1.95 \%$ can be classified as mild in flavor and are well accepted for consumption as fresh fruit (Paiva et al., 1997). All the loquat cultivars fall into this group (Table 1).

One of the ways most commonly used for evaluation of the fruit flavor is through the TSS/TTA ratio (Antunes et al., 2010).

The Mizauto cultivar characterized by having the highest soluble solids ( $\left.15.47^{\circ} \mathrm{Brix}\right)$ and lower total acidity ( $0.44 \mathrm{~g}$ citric acid/100 g) which resulted in a higher ratio (35.21). Furthermore, this cultivar stood out by presenting higher $\mathrm{pH}$ values (Table 1 ). These characteristics demonstrate that Mizauto is the cultivar that has the highest sweetness and is the least acidic, probably reflecting in a better sweet-acid balance which is extremely important and desirable for fresh consumption. Although it was the cultivar with smallest dimensions and lowest weight, it seems to be the most suitable cultivar for consumption in fresh form. According to Jonathan \& Liliam (2009) the loquat fruit can be eaten fresh and without the peel, because of its good soluble solids.

On the other hand, the Kurisaki and Mizuho cultivars differed from the others presenting the least amount of soluble solids (8.63 and $9.4^{\circ}$ Brix, respectively), higher total acidity
(1.22 and 1.10, respectively), lower ratio (7:07 and 8:55, respectively) and lower $\mathrm{pH}$ (2.70 and 2.78, respectively) (Table 1). That is, these two cultivars characterized by presenting less sweet and more acidic fruit. These characteristics are not desirable for fresh consumption; more acidic fruit may be interesting for processing.

Regarding the soluble solids, the values found in this study were higher than those found by Wanga et al. (2015). This difference may be explained by the higher temperatures of subtropical conditions since environments with higher temperatures and higher photoperiods provide fruits with more soluble solids (Maro et al., 2014). Regarding the fruit firmness, the range of variation was from 14.30 (Mizauto) to $56.48 \mathrm{~N}$ (Mizuho) (Table 1). The Mizuho differed from the others, being the cultivar that presented the most firm fruits, however Mizauto had the lowest firmness which may reflect in juicier fruits. Importantly, the difference in the firmness of the cultivars may be due to differences in the fruit maturation stage and not just the difference due to cultivar, because although great care has been taken, we cannot guarantee that all the fruits of all cultivars were picked on at an equal maturation stage. The Mizauto was the least firm cultivar and coincidentally this cultivar presented the highest sweetness, highest ratio and lowest acidity, possibly due to greater maturity of its fruits. According to Singh et al. (2010) the loquats have low firmness in the different cultivars.

In relation to the fruit color of different loquat cultivars, there was no significant difference for the $\mathrm{L}^{*}, \mathrm{~b}^{*}$, Croma and Hue color parameters (Table 1). This demonstrates that the loquat cultivars have similar black and yellow color intensity. Since color parameter $\mathrm{a}^{*}$ significantly varied from 6.71 (Kurisaki) to 11.53 (Fukuhara) (Table 1), the Fukuhara cultivar characterized by having more intense red color when compared to the other cultivars. These results are in agreement with Zhang \& Shao (2015) who also found $L^{*}$ values around 68.00 in different loquat cultivars, but the $b^{*}$ values were lower than those found in the present study. As noted for firmness, color may also reflect differences among cultivars and possible differences in the fruit maturation stage.

\subsection{Physicochemical and textural analyses of loquat jelly formulations}

The average values and the average test of the physicochemical and texture properties of different formulations are shown in Table 2 .

The loquat jelly formulations showed significant differences $(\mathrm{p} \leq 0.05)$ for $\mathrm{pH}$, total acidity, color parameters $\mathrm{a}^{*}$ and $\mathrm{b}^{*}$, hardness, 
Table 2. Soluble solids (SS), $\mathrm{pH}$, total acidity (TA), color $\left(\mathrm{L}^{\star}, \mathrm{a}^{\star}, \mathrm{b}^{\star}\right.$, Croma e $\left.{ }^{\circ} \mathrm{Hue}\right)$, hardness (Hard), adhesiveness (Adhe), springiness (Spr), cohesiveness (Cohe), gumminess (Gum) and chewiness (Chew) in loquat jelly formulations.

\begin{tabular}{ccccccccccccccc}
\hline Cultivars & SS & pH & TA & $\mathbf{L}^{\star}$ & $\mathbf{a}^{\star}$ & $\mathbf{b}^{\star}$ & Croma & Hue & Hard & Adhe & Spr & Cohe & Gum & Chew \\
\hline Fukuhara & $64.33^{\mathrm{a}}$ & $3.90^{\mathrm{a}}$ & $0.02^{\mathrm{b}}$ & $59.83^{\mathrm{b}}$ & $1.93^{\mathrm{c}}$ & $8.83^{\mathrm{b}}$ & $8.89^{\mathrm{b}}$ & $77.67^{\mathrm{b}}$ & $1.93^{\mathrm{a}}$ & $2.76^{\mathrm{a}}$ & $0.98^{\mathrm{a}}$ & $0.49^{\mathrm{a}}$ & $0.96^{\mathrm{a}}$ & $0.95^{\mathrm{a}}$ \\
Mizumo & $61.33^{\mathrm{a}}$ & $3.50^{\mathrm{ab}}$ & $0.04^{\mathrm{ab}}$ & $52.47^{\mathrm{b}}$ & $2.10^{\mathrm{c}}$ & $6.27^{\mathrm{b}}$ & $6.65^{\mathrm{b}}$ & $71.48^{\mathrm{b}}$ & $1.19^{\mathrm{b}}$ & $1.39^{\mathrm{b}}$ & $0.97^{\mathrm{a}}$ & $0.35^{\mathrm{bc}}$ & $0.41^{\mathrm{b}}$ & $0.39^{\mathrm{b}}$ \\
Kurisaki & $67.67^{\mathrm{a}}$ & $3.43^{\mathrm{b}}$ & $0.06^{\mathrm{a}}$ & $68.85^{\mathrm{ab}}$ & $8.35^{\mathrm{a}}$ & $28.77^{\mathrm{a}}$ & $29.96^{\mathrm{a}}$ & $73.48^{\mathrm{b}}$ & $0.47^{\mathrm{c}}$ & $1.24^{\mathrm{b}}$ & $0.98^{\mathrm{a}}$ & $0.39^{\mathrm{b}}$ & $0.18^{\mathrm{c}}$ & $0.18^{\mathrm{c}}$ \\
Mizuho & $66.67^{\mathrm{a}}$ & $3.57^{\mathrm{ab}}$ & $0.07^{\mathrm{a}}$ & $64.56^{\mathrm{ab}}$ & $5.25^{\mathrm{b}}$ & $22.30^{\mathrm{a}}$ & $22.90^{\mathrm{a}}$ & $76.75^{\mathrm{b}}$ & $0.35^{\mathrm{c}}$ & $1.25^{\mathrm{b}}$ & $0.97^{\mathrm{a}}$ & $0.43^{\mathrm{ab}}$ & $0.15^{\mathrm{c}}$ & $0.15^{\mathrm{c}}$ \\
Mizauto & $69.00^{\mathrm{a}}$ & $3.80^{\mathrm{ab}}$ & $0.02^{\mathrm{b}}$ & $76.03^{\mathrm{a}}$ & $1.23^{\mathrm{c}}$ & $33.53^{\mathrm{a}}$ & $33.52^{\mathrm{a}}$ & $86.90^{\mathrm{a}}$ & $0.13^{\mathrm{d}}$ & $0.07^{\mathrm{c}}$ & $0.89^{\mathrm{a}}$ & $0.27^{\mathrm{c}}$ & $0.03^{\mathrm{c}}$ & $0.03^{\mathrm{c}}$ \\
\hline
\end{tabular}

Mean values with common letters in the same column indicate that there is no significant difference among samples ( $\mathrm{p} \leq 0.05)$ from Tukey's mean test. Total acidity: $\mathrm{g}$ citric acid/100 $\mathrm{g}$.w.

adhesiveness, cohesiveness, gumminess and chewiness. For the soluble solids, color parameter $\mathrm{L}^{*}$ and springiness, differences were not observed. In order to facilitate the visualization, the principal component analysis (PCA) was generated to correlate the physicochemical parameters and texture data with loquat jelly (Figure 1).

The soluble solids of the loquat jelly ranged from 61.33 to $69.00^{\circ} \mathrm{Brix}$ (Mizumo and Mizauto cultivars, respectively) (Table 2). It was expected that the soluble solids content would not significantly differ because although the loquat cultivars showed different soluble solids, during the preparation of the jelly the final brix degree was fixed. Comparative studies of jelly, jam and juice prepared from loquats showed that the solids of jellies ranges from $65-70^{\circ}$ Brix (Rakesh et al., 2011).

The $\mathrm{pH}$ values varied from 3.43 to 3.90 (Kurisaki and Fukuhara cultivars, respectively) (Table 2). Through the PCA (Figure 1) and the average table (Table 2) it can be seen that Fukuhara (F1) and Mizauto (F5) cultivars stood out due to their higher $\mathrm{pH}$ (3.90 and 3.80, respectively). The higher $\mathrm{pH}$ of the prepared jelly from these cultivars corroborates the higher $\mathrm{pH}$ of these fruits in natura.

The acidity of the jellies ranged from 0.02 to $0.07 \mathrm{~g}$ citric acid/100 g (Table 2). According to the PCA and the average table (Figure 1 and Table 2) the jellies prepared with Kurisaki (F3) and Mizuho (F4) cultivars stood out by presenting the highest acidity ( 0.06 and $0.07 \mathrm{~g}$ citric acid/100 g, respectively). As for $\mathrm{pH}$, jellies with higher acidity were those obtained from the fresh cultivars that showed the highest values.

Regarding the color, the color parameter $\mathrm{L}^{*}$ ranged from 52.47 to 76.03 , the color parameter $\mathrm{a}^{\star}$ ranged from 1.23 to 8.35 and color parameter $\mathrm{b}^{*}$ ranged from 6.27 to 33.53 (Table 2). According to the PCA and the average table (Figure 1 and Table 2) in relation to the color parameter $\mathrm{a}^{*}$, the jelly obtained from Kurisaki (F3) and Mizuho (F4) cultivars stood out due to their higher intensity of yellow color (8.35 and 5.25 respectively), compared to the color parameter $\mathrm{L}^{*}$ and $\mathrm{b}^{*}$, Mizuato (F5) stood out by presenting the highest intensity of black and red/orange color (76.03 and 33.53 respectively). Overall, compared to the fruit in natura, the jelly is less intense in yellow/red color and is darker, possibly because of the concentration and the reactions that occur during the heating, such as the Maillard reaction.

Regarding the texture, it can be seen through PCA (Figure 1) and the average table (Table 2) that the jelly obtained from Fukuhara (F1) and Mizumo (F2) cultivars characterized by presenting the highest values for all texture parameters evaluated.

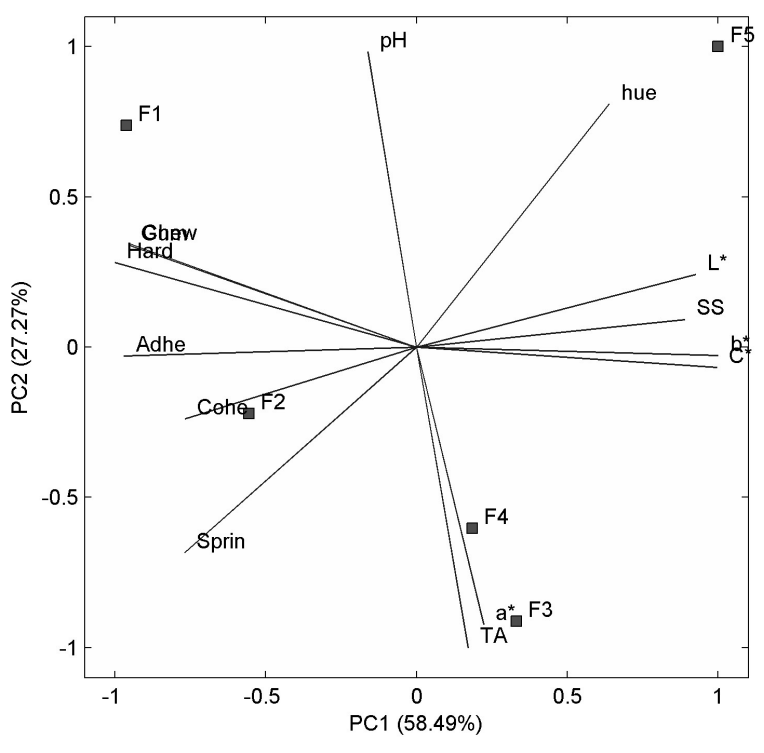

Figure 1. Principal component analysis (PCA) for the different samples of loquat jelly and physicochemical and texture properties. Fukuhara (F1); Mizumo (F2); Kurisaki (F3); Mizuho (F4); Mizauto (F5); Total acidity (TA), g citric acidy/100 g fw; soluble solids (SS), ${ }^{\circ}$ Brix; Hard., Hardness (N); Adhe., Adhesiveness (N/s); Sprin, Springiness; Cohe, Cohesiveness; Gummi, Gumminess (N); Chew, Chewiness.

The jelly obtained from the Fukuhara cultivar (F1) showed greater cohesiveness $(0.49)$ and jellies produced by the Fukuhara (F1) and Mizumo (F2) cultivars showed the highest hardness values (1.93 and $1.19 \mathrm{~N}$, respectively), adhesiveness (2.76 and 1.39 respectively), gumminess ( 0.96 and 0.41 , respectively) and chewiness ( 0.95 and 0.39 , respectively) (Table 2 and Figure 1 ). The jellies obtained from Fukuhara and Mizumo cultivars characterized by being more rigid, firm, elastic and adhesive.

Several factors may explain the change of texture among the jellies prepared from different loquat cultivars; among them the amount of sugar present in each cultivar, $\mathrm{pH}$, acidity and soluble pectin content are factors that may influence the gelling and therefore the texture of the final product (Souza et al., 2014).

\subsection{Sensory analysis of the loquat jelly formulations}

Through analysis of variance a significant difference was verified among the jellies obtained from different loquat cultivars for all the evaluated sensory attributes $(\mathrm{p} \leq 0.05)$. The mean scores 
and the mean test for the sensory characteristics evaluated in loquat jelly formulations are shown in Table 3.

Figure 2 shows the 3-way external map that represents the distribution of consumers, samples, consumer sensory attributes related to acceptance and physicochemical and texture. The PARAFAC was fixed with 2 factors, which led to a concordia value of $62 \%$ and a variance value of $43 \%$.

Through TWEPM (Figure 2) and the average table for sensory parameters (Table 3), it can be seen that the most accepted jellies were processed with the Kurisaki (F3) and Mizuho (F4) cultivars, followed by Mizumo (F2). These jellies showed good acceptability with average scores situated between the hedonic terms "liked moderately" and "liked very much". The jelly obtained from Fukuhara (F1) and Mizauto (F5) cultivars were less accepted, having less sensory acceptability than the other formulations with average scores situated between the hedonic terms "dislike moderately" and "liked moderately."

Table 3. Sensory characteristics of the loquat jellies obtained from different cultivars.

\begin{tabular}{ccccc}
\hline & \multicolumn{4}{c}{ Sensory Parameters } \\
\cline { 2 - 5 } Formulations & Color & Taste & Consistency & $\begin{array}{c}\text { Overall } \\
\text { Liking }\end{array}$ \\
\hline Fukuhara - F1 & $5.35^{\mathrm{c}}$ & $5.72^{\mathrm{b}}$ & $3.90^{\mathrm{c}}$ & $4.89^{\mathrm{c}}$ \\
Mizumo - F2 & $7.52^{\mathrm{ab}}$ & $6.78^{\mathrm{ab}}$ & $5.43^{\mathrm{b}}$ & $6.33^{\mathrm{b}}$ \\
Kurisaki - F3 & $7.80^{\mathrm{a}}$ & $7.17^{\mathrm{a}}$ & $6.94^{\mathrm{a}}$ & $7.30^{\mathrm{a}}$ \\
Mizuho - F4 & $7.05^{\mathrm{b}}$ & $7.11^{\mathrm{a}}$ & $7.04^{\mathrm{a}}$ & $7.11^{\mathrm{a}}$ \\
Mizauto - F5 & $5.33^{\mathrm{c}}$ & $6.20^{\mathrm{bc}}$ & $5.88^{\mathrm{b}}$ & $5.91^{\mathrm{b}}$ \\
\hline
\end{tabular}

Mean values with common letters in the same column indicate that there is no significant difference between samples ( $\mathrm{p} \leq 0.05)$ by Tukey's mean test.

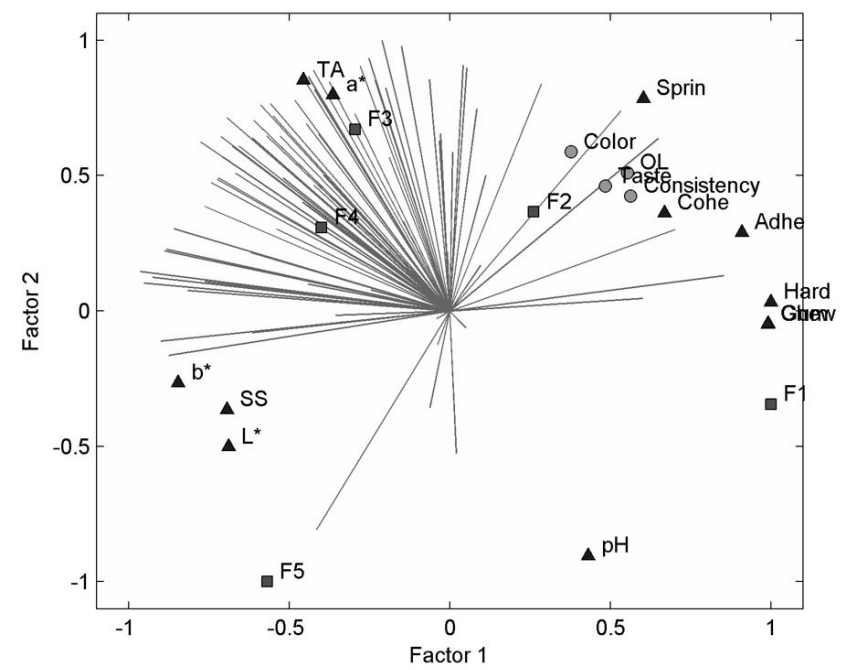

Figure 2. Three-way external preference map (TWEPM) for sensory attributes (color, taste, consistency and overall liking [OL]), physicochemical properties (color $\mathrm{L}^{*}, \mathrm{a}^{*}$, and $\mathrm{b}^{*}, \mathrm{pH}$, total acidity [TA], and soluble solids [SS]) and rheological parameters (hardness [Hard], adhesiveness [Adhe], springiness [Sprin], cohesiveness [Cohe], gumminess [Gum] and chewiness [Chew]) for the loquat jelly formulations. Fukuhara (F1); Mizumo (F2); Kurisaki (F3); Mizuho (F4); Mizauto (F5).
Regarding the physicochemical characteristics, through the TWEPM (Figure 2) and the average table for sensory acceptance and physicochemical parameters (Tables 2 and 3), it can be seen that the most accepted jellies (Kurisaki-F3 and Mizuho -F4) were characterized by having the highest total acidity and highest color parameter $\mathrm{a}^{\star}$, which means more acidic and more intense red color jelly. The less accepted jellies (Fukuhara - F1 and Mizauto - F5) were characterized by having higher $\mathrm{pH}$ values, thus being less acidic. In addition, the formulation obtained with the Fukuhara (F1) cultivar was characterized by having the highest values for the texture parameters and the formulation obtained with Mizauto (F5) cultivar showed higher $\mathrm{b}^{\star}$ and $\mathrm{L}^{*}$ color parameters values and higher soluble solids content, characterized by having a darker, more yellow color intensity and sweeter jelly.

From the sensory acceptance results it can be seen that the loquat processing is feasible due to high sensory acceptance of the jellies obtained. Because of the higher sensory acceptance, Kurisaki and Mizuho cultivars are the most suitable for processing in the form of jelly, followed by the Mizumo cultivar. From this study we can see that the consumer has a preference for jellies with higher acidity, lower sweetness, brighter and more intense red color and also prefer a less rigid and firm jelly.

Jellies made with the other cultivars (Fukuhara and Mizauto) had lower sensory acceptability, but that does not mean impossibility of processing because adjustments in processing/formulation can change the undesirable characteristics. Combined with sensory acceptance, factors such as adaptation, susceptibility to pests, production costs and yield should also be considered to indicate what the most interesting cultivars are for industrialization.

In this study it was verified that the less interesting cultivars for fresh consumption seem to be the most appropriate for processing. The Kurisaki and Mizuho cultivars that were less interesting cultivars for fresh consumption because of lower sweetness, higher acidity and lower ratio were the most suitable for processing in the form of jelly. The Mizauto cultivar, that although having smaller dimensions and lower unit weight, appears to be one of the most suitable for consumption in fresh form due to higher sweetness, lower acidity and higher ratio was, however, among the least accepted cultivars after processing in the form of jelly. This fact is extremely interesting because cultivars that seems to be not suitable for fresh consumption were exactly the most suitable for processing.

\section{Conclusions}

The different studied loquat cultivars (Fukuhara, Kurisaki, Mizumo, Mizuho and Mizauto) had different physical and physicochemical characteristics which resulted in jellies with different physicochemical, rheological and sensory characteristics. The consumer prefers a more acidic, less sweet, less firm, softer loquat jelly, clearer with a more intense red color. Based on sensory acceptance the most suitable loquat cultivars for jelly processing are Kurisaki and Mizuho.

\section{Acknowledgements}

To FAPEMIG, CNPq and CAPES for the financial support. 


\section{References}

Antunes, L. E. C., Ristow, N. C., Krolow, A. C., Carpenedo, S., \& Reisser, C., Jr. (2010). Yield and quality of strawberry cultivars. Horticultura Brasileira, 28(2), 222-226. http://dx.doi.org/10.1590/ S0102-05362010000200015.

Bourne, M. C. (1968). Texture profile of ripening pears. Journal of Food Science, 33(2), 223-226. http://dx.doi.org/10.1111/j.1365-2621.1968. tb01354.x.

Cai, C., Chen, K., Xu, W., Zhang, W., Li, X., \& Ferguson, X. (2006). Effect of 1-MCP on postharvest quality of loquat fruit. Postharvest Biology and Technology, 40(2), 155-162. http://dx.doi.org/10.1016/j. postharvbio.2005.12.014.

Curi, P. N., Pio, R., Moura, P. H. A., Tadeu, M. H., Nogueira, P. V., \& Pasqual, M. (2015). Production of blackberry and redberry in Lavras - MG, Brazil. Ciência Rural, 45(8), 1368-1374. http://dx.doi. org/10.1590/0103-8478cr20131572.

Ferreres, F., Gomes, D., Valentao, P., Gonçalves, R., Pio, R., Chagas, E. A., Seabra, R. M., \& Andrade, P. B. (2009). Improved loquat (Eriobotrya japonica Lindl.) cultivars: Variation of phenolics and antioxidative potential. Food Chemistry, 114(3), 1019-1027. http:// dx.doi.org/10.1016/j.foodchem.2008.10.065.

Friedman, H. H., Whitney, J. E., \& Szczesniak, A. S. (1963). The texturometera new instrument for objective texture measurement. Journal of Food Science, 28(4), 390-396. http://dx.doi.org/10.1111/j.1365-2621.1963. tb00216.x.

Gennadios, A., Weller, C. L., Hanna, M. A., \& Froning, G. W. (1996). Mechanical and barrier properties of egg albumen films. Journal of Food Science, 61(3), 585-589. http://dx.doi.org/10.1111/j.1365-2621.1996. tb13164.x.

Gong, R. G., Lai, J., Yang, W., Liao, M. A., Wang, Z. H., \& Linag, G. L. (2015). Analysis of alterations to the transcriptome of Loquat (Eriobotrya japonica Lindl.) under low temperature stress via de novo sequencing. Genetics and Molecular Research, 14(3), 94239436. http://dx.doi.org/10.4238/2015.August.14.6. PMid:26345876.

Hasegawa, P. N., Faria, A. F., Mercadante, A. Z., Chagas, E. A., Pio, R., Lajolo, F. M., Cordenunsi, B. R., \& Purgatto, E. (2010). Chemical composition of five loquat cultivars planted in Brazil. Ciência e Tecnologia de Alimentos, 30(2), 252-559. http://dx.doi.org/10.1590/ S0101-20612010000200040.

Instituto Adolfo Lutz - IAL. (2005). Normas analíticas do Instituto Adolfo Lutz. São Paulo: IAL.

Jonathan, H. C., \& Liliam, C. (2009). Loquat growing in the Florida Home Landscape. Gainesville: UF University of Florida IFAS Extension.

Lin, S. Q. (2007). World loquat production and research with special reference to China. Acta Horticulturae, 750(1), 37-44. http://dx.doi. org/10.17660/ActaHortic.2007.750.2.

Maro, L. A. C., Pio, R., Guedes, M. N. S., Abreu, C. M. P., \& Curi, P. N. (2013). Bioactive compounds, antioxidant activity and mineral composition of fruits of raspberry cultivars grown in subtropical areas in Brazil. Fruits, 68(3), 209-217. http://dx.doi.org/10.1051/ fruits/2013068.

Maro, L. A. C., Pio, R., Guedes, M. N. S., Abreu, C. M. P., \& Moura, P. H. A. (2014). Environmental and genetic variation in the post-harvest quality of raspberries in subtropical areas in Brazil. Acta Scientiarum, 36(3), 323-328. http://dx.doi.org/10.4025/actasciagron.v36i3.18050.

Morton, J. F. (1987). Loquat. In: Fruits of warm climates (pp. 103-108). Winterville: Creative Resource Systems.

Nogueira, P. V., Silva, D. F., Pio, R., Silva, P. A. O., Bisi, R. B., \& Balbi, R. V. (2015). Germinação de pólen e aplicação de ácido bórico em botões florais de nespereiras. Bragantia, 74(1), 9-15. http://dx.doi. org/10.1590/1678-4499.0264.
Nunes, C. A., Pinheiro, A. C. M., \& Bastos, S. C. (2011). Evaluating consumer acceptance tests by three-way internal preference mapping obtained by parallel factor analysis (PARAFAC). Journal of Sensory Studies, 26(2), 167-174. http://dx.doi.org/10.1111/j.1745459X.2011.00333.x.

Ojima, M., Campo Dallorto, F. A., Barbosa, W., Martins, F. P., \& Santos, R. R. (1999). Cultura da nespereira (36 p.). Campinas: Instituto Agronômico.

Paiva, M. C., Manica, I., Fioravanço, J. C., \& Kist, H. (1997). Caracterização química dos frutos de quatro cultivares e de duas seleções de goiabeira. Revista Brasileira de Fruticultura, 19(1), 57-63. http:// dx.doi.org/10.1590/S0100-29452002000100061.

Pinheiro, A. C. M., Nunes, C. A., \& Vietoris, V. (2013). SensoMaker: a tool for sensorial characterization of food products. Ciência $e$ Agrotecnologia, 37(3), 199-201. http://dx.doi.org/10.1590/S141370542013000300001 .

Pio, R., Dall, B., Chagas, E. A., Ojima, M., \& Cia, P. (2007). Produção de cultivares de nespereira na região Leste paulista. Pesquisa Agropecuaria Brasileira, 42(7), 1053-1056. http://dx.doi.org/10.1590/ S0100-204X2007000700020.

Rakesh, S., Joshi, V. K., \& Rana, J. C. (2011). Nutritional composition and processed products of Quince (Cydonia ablongamill.). Indian Journal of Natural Products and Resources, 2(3), 354-357.

Sanches, J., Cia, P., Valentim, S. R. T., Benato, E., Chagas, E. A., \& Pio, R. (2011). Modified atmosphere and refrigeration for the postharvest conservation of 'Fukuhara' loquat. Bragantia, 70(2), 455-459. http:// dx.doi.org/10.1590/S0006-87052011000200029.

Silva, P. S. L., As, W. R., Mariguele, K. H., Barbosa, A. P. R., \& Oliveira, O. F. (2002). Distribuição do teor de sólidos solúveis totais em frutos de algumas espécies de clima temperado. Revista Caatinga, 15, 19-23.

Singh, B., Gairola, S., Kumar, D., Gupta, V., \& Bansal, P. (2010). Pharmacological potential of ErioBotrya Japonica-AN. International Research Journal of Pharmacy, 1(1), 95-99.

Souza, V. R., Pereira, P. A. P., Pinheiro, A. C. M., Lima, L. C. O., \& Pio, R. (2014). Analysis of the subtropical blackberry cultivar potential in jelly processing. Journal of Food Science, 79(9), 1776-1781. http:// dx.doi.org/10.1111/1750-3841.12565. PMid:25154800.

Souza, V. R., Pereira, P. A. P., Teixeira, T. R., Silva, T. L. T., Pio, R., \& Queiroz, F. (2015). Influence of processing on the antioxidant capacity and bioactive compounds in jellies from different blackberry cultivars. Journal of Food Science and Technology, 50(9), 1658-1665. http://dx.doi.org/10.1111/ijfs.12819.

Stone, H. S., \& Sidel, J. L. (1993). Sensory evaluation practices. San Diego: Academic Press.

Van Vliet, T. (1991). Terminology to be used in cheese rheology. International Dairy Federation, 268, 5-15.

Wakeling, I. N., \& MacFie, H. J. H. (1995). Designing consumer trials balanced for first and higher orders of carry-over effect when only a subset of k samples from $\mathrm{t}$ may be tested. Food Quality and Preference, 6(4), 299-308. http://dx.doi.org/10.1016/0950-3293(95)00032-1.

Wanga, B., Shifeng, C., Yaqiong, D., Yunxia, L., \& Yonghua, Z. (2015). Effect of ethanol treatment on disease resistance againstanthracnose rot in postharvest loquat fruitKaituo. Scientia Horticulturae, 188(1), 115-121. http://dx.doi.org/10.1016/j.scienta.2015.03.014.

Zhang, W., Zhao, X., Sun, C., Li, X., \& Chen, K. (2015). Phenolic composition from different loquat (Eriobotrya japonica Lindl.) cultivars grown in china and their antioxidant properties. Molecules (Basel, Switzerland), 20(1), 542-555. http://dx.doi.org/10.3390/ molecules20010542. PMid:25569513.

Zhang, X., \& Shao, X. (2015). Characterization of polyphenol oxidase and peroxidase and the role in browning of loquat fruit. Journal of Food Science, 33(2), 109-117. http://dx.doi.org/10.17221/384/2014-CJFS. 